\title{
Teachers' Struggling in the Midst of Reform: Teachers' Implementation of Reformed Ninth Grade Physics Curriculum
}

\author{
Nuri Balta* \\ Department of Educational Sciences, Canik Basari University, 55080-Samsun-TURKEY
}

\begin{tabular}{|c|c|}
\hline \multicolumn{2}{|c|}{ Faculty of Education, Karadeniz Technical University, Trabzon - TURKEY } \\
\hline Article history & A new national physics curriculum has recently been implemented across \\
\hline $\begin{array}{l}\text { Received: } \\
22.03 .2016\end{array}$ & $\begin{array}{l}\text { Turkey. This paper examines the experience of physics teachers through } \\
\text { their experience of implementing the ninth grade physics curriculum all }\end{array}$ \\
\hline $\begin{array}{l}\text { Received in revised form: } \\
23.05 .2016\end{array}$ & $\begin{array}{l}\text { over the Turkey. A cross-sectional survey design was used to examine to } \\
\text { what extent physics teachers comply with, teach and comprehend the } \\
\text { curriculum. Data which were collected within the spring semester of }\end{array}$ \\
\hline $\begin{array}{l}\text { Accepted: } \\
24.05 .2016\end{array}$ & $\begin{array}{l}\text { 2014-2015 academic year, was gathered via an online questionnaire that } \\
\text { was applied to } 71 \text { physics teachers. Chi square analysis was conducted to }\end{array}$ \\
\hline Key words: & see whether scores determined for each main topics changed according to \\
\hline $\begin{array}{l}\text { physics education; physics } \\
\text { curriculum; curriculum reforms }\end{array}$ & $\begin{array}{l}\text { school type, teaching experience, education level, graduated faculty and } \\
\text { gender. Results indicated that a considerable part of participants were not } \\
\text { even aware of the limitations of the curriculum and almost half of them } \\
\text { did not comply with these limitations in their classes. Moreover, it was } \\
\text { determined that an important part of participants could explain the } \\
\text { meaning of objectives that were newly added to the curriculum. } \\
\text { Furthermore, upon analyzing the findings that were acquired in terms of } \\
\text { different parameters (gender, graduated faculty, school type and school } \\
\text { experience); some important results were obtained within the scope of the } \\
\text { study. This study implies that reforms done on the curricula require } \\
\text { cautions, that is, without pilot studies modifications in the curricula may } \\
\text { arise significant problems. }\end{array}$ \\
\hline
\end{tabular}

\section{Introduction}

In line with the necessities of the time, curricula play an essential role in the process of transition from collective education to personal education. The curricula that adopt a structure from easy to difficult, from simple to complex, from concrete to abstract in all disciplines aim to raise individuals who will learn learning in the most general sense (Ayvac1, 2010, Sarıkaya vd., 2010). Present curricula assume that all students could be educated, in other words, there is no student that cannot be educated (Arslan, Ercan \& Tekbiyık, 2012). In this case, curricula should be general enough to enable all students to achieve certain goals; but they also should be special enough personal differences (Tekbiyık, 2010). Educational institutions will be able 
to raise qualified individuals that are needed by modern societies only when they become competent enough to realize these goals.

The curricula that are encountered as a necessity of today's modern life, have a broad field of application in various countries, constantly renew themselves and are open to changes have started to be applied in our country as well. In this context, the year 2004-2005 is accepted as a reform for the curricula of our country (Erdoğan \& Köseoğlu, 2012). Compared to the applications of previous years, these curricula use a full change in the positions and the roles of teachers-students in intra-class activities (Tekbiyık, 2010). Accordingly, the learning environments based on the usual principle of active teacher have been replaced by environments based on the principle of active learner (Sağlam Arslan, et al 2013). In this context, "personal differences", interests and needs, motivations, prior knowledge of learners have become the major factors of education rather than just details that are given while fully teaching the subjects in the class. In addition to this, as is already known, real applications could usually be different from what the curricula predict. Being the implementers of curricula; teachers act like the sole architects to build a bridge between intra-class applications and curricula. In this case, the attitudes, beliefs and views of teachers play a very important role in the success of curricula today, as it has always been in all periods (Özsevgeç, 2007).

A number of studies have investigated the convenience of curricula, which are applied gradually and ground on a constructivist learning approach, for the conditions in our country and their state of being applied especially by teachers. Studies on the attitudes, beliefs and sufficiency of teachers regarding curricula (for instance, Toptaş, 2006; Bulut, 2007; Özmantar et al. 2009) have revealed that teachers are unable to internalize and thus apply the change that is defined as a reform in curricula.

Considering the historical development of Physics lesson curriculum being applied in Turkey; it is observed that the curricula that used to be prepared as subject lists until the 1960s started to be organized in a way to contain goals-behaviors as from 1993 and they underwent a radical change with a country-wide educational reform in 2007 (Paliç, 2014). Being related with a number of conditions like subjects that are taught in different class levels, learning approach that is adopted and assessment-evaluation approaches; this change was reapproached after a short time and the present physics lesson curricula were prepared. The 2007 curriculum was updated by a commission that was formed in cooperation with MEBTUBITAK in 2013 and contained teachers and academicians. It is observed that the update studies are generally based on the principle of accommodating the curricula being applied since 2007 to country conditions, but the general structure and the learning approach remain the same. This condition shows that a student-centered education rises to prominence and a student profile that learns by practicing, feels responsible for her/his own learning and learns learning keeps its sustainability. Considering the efficiency and importance of exploration method in physics education (Daramola \& Omosewo, 2012); we clearly see the necessity of student-centered education that is adopted by curricula.

Today where instructive-centered approaches have been replaced by learner-centered approaches, the roles and tasks of teachers have become more important and maybe more difficult than ever. In this context; it is known that teachers have a task of organizing and controlling the learning environment, guiding the students and giving feedbacks apart from transferring their knowledge as is. However, national studies (Akdeniz \& Paliç, 2012; Balta, 2015; Sağlam Arslan, et al. 2009; Tekbıyık \& Akdeniz, 2008;) show that teachers teach their 
lessons theoretically based on some reasons (like course hour, class size, field knowledge) and they do not fulfil their responsibilities regarding the 2007 physics curriculum. Teachers' failure in adopting the philosophy of new curricula due to being unable to give up on their old habits (Tekbiyık, 2010) is considered the primary obstacle in applying the curricula in classrooms. Regarding this issue, it is required to investigate to what extent the teachers recognize and consider the physics curriculum.

The studies focusing on the thoughts of physics teachers about the curricula that were carried into effect in 2007 (for instance, Ayvac1, 2010; Kapucu, 2010) showed that the teachers did not have the competence required by the curricula. However, another relevant study (Arslan, Ercan \& Tekbiy1k, 2012) showed that teachers generally had positive views and perceptions about the structure of curricula and they comprehended the acquisitions in curricula.

\section{Turkish physics curriculum}

Turkey started to make radical reforms in the national curricula, in all subjects, in 2004-2005 academic year and in 2007-2008 academic year a substantively different curriculum was applied for physics at high school level. However, because of both the complexity of the curriculum and the addition of new topics, teachers protested it with letters of complaint and as a result, the curriculum was renewed in 2013 by the Ministry of National Education.

There are 43 objectives and 93 follow up explanations of the objectives in the 2013 grade 9 curriculum. To the structure the curriculum is the form of objectives and the related explanations which usually focuses on the new concepts and the limitations imposed on the topics. For instance, in the force and motion unit there are five objectives related to Newton's laws of motion. The objective and subsequent explanations for the third objective are as follows:

\subsubsection{Newton's Laws of Motion}

9.3.3.3. Explore the relationship between force, acceleration and mass.

a. Provide students to examine and discuss the dependent, independent and control variables in the Galileo's inclined plane experiment.

b. Prepare an environment for students to drive a mathematical model between net force, acceleration and mass by doing experiments.

c. Not enter into mathematical calculations other than applications with single mass (Turkish physics curriculum, 2013. p. 6).

The number of objectives and the number of related explanations in the grade 9 curriculum is given in Table 1.

Table 1. Units in the grade 9 curriculum and statistics for objectives

\begin{tabular}{lcccc}
\hline Unit & $\begin{array}{c}\text { No of } \\
\text { objectives }\end{array}$ & $\begin{array}{c}\text { Number of } \\
\text { explanation for } \\
\text { objectives }\end{array}$ & $\begin{array}{c}\text { Explanations } \\
\text { per objectives }\end{array}$ & $\begin{array}{c}\text { \# of } \\
\text { limitations }\end{array}$ \\
\hline Introduction to physics & 4 & 13 & 0.31 & 1 \\
Matter and its properties & 8 & 20 & 0.40 & 8 \\
Force and motion & 13 & 31 & 0.42 & 5 \\
Energy & 6 & 16 & 0.38 & 2 \\
Heat and temperature & 12 & 18 & 0.67 & 2 \\
Total & 43 & 98 & 0.44 & \\
\hline
\end{tabular}


Being based on a constructivist theory, the 2007 physics lesson curriculum was revised according to the conditions in our country as grounding on a single theory would dispel the advantages of others (MEB, 2013). Following the revision in 2013, the changes in the views of teachers have become very important. Regarding this condition, answers will be sought for the following questions in this study:

1. What is the level of physics teacher knowledge on the limitations imposed by the curriculum and to what extent do they comply with these limitations?

2. What is the level of physics teacher knowledge on the new concepts added to the curriculum and to what extent do they teach these concepts in their courses?

3. To what extent do teachers comprehend the objectives of the curriculum?

4. How do the results obtained from the aforementioned research questions vary across gender, graduated faculty, school type and school experience?

Turkish grade 9 physics curriculum, referred hereafter as physics curriculum or curriculum was the focus of this study.

\section{Method}

This is an observational study which means that the information about the participants are gathered without manipulating the study environment. Data was collected to make inferences about the population of interest at one point in time. In other words, a snapshot of the population have been taken about which the data collected. In this context, a crosssectional survey design (Creswell, 2012) was used to examine to what extent physics teachers comply with, teach and comprehend the grade 9 physics curriculum. Data for this study were collected within the spring semester of 2014-2015 academic year. In terms of the collected data and research questions, the study is mainly quantitative.

\section{Participants}

In order to the sample be representative, to reach physics teachers all around Turkey and collected data without expense, physics teachers' Facebook groups were exploited. Physics teacher participants from high schools were sourced from 26 different cities in Turkey. These were 84 physics teachers from different Facebook groups who participated in the survey published on the web. Of them 13 were excluded because of double data entry and incomplete data entry. In all, a total of 71 teachers completed the survey and that constituted a voluntary population successfully took part in this study. Table 2 is a breakdown of participants by gender, type of school, faculty graduated, degree of education, job experience and several other questions to reveal additional characteristic of the physics teachers took part in this study.

As seen from Table 2 the male and the public school teachers are approximately twice as much female and private school teachers respectively. Similarly, the teachers from Anatolia high school and the teachers having bachelor degree are also roughly more than the sum of other classifications. Further, among the teachers partook to this study those having teaching experiences between 11-20 years has the biggest proportion. It is worth to mention that the percentages of the groups are not equal, but these differences more or less represent the percentages of teachers in each groups across Turkey. For example, in 2013-2014 academic 
year the percentage of male and female teachers in high schools were $\% 54$ and $\% 46$ and that of public and private schools are \%81 and \%19 respectively (TEDMEM, 2015).

Table 2 indicates that physics teachers generally have examined the physics curriculum. That is, the total proportion of teachers who never, very little and little examined the curriculum is only $8.4 \%$. However, the rate at which teachers issue the curriculum is that much. Namely, the percentage of teachers who never, very little and little talk on the curriculum is $18.3 \%$. On the other, even though it is desired teachers to use the curriculum as a guide in planning teaching physics, there are teachers that use the course book as a guide $(9.9 \%)$. Finally, of the teachers who partook to this study $62 \%$ were teachers teaching at all high school grades.

Table 2. Demographics of the participants

\begin{tabular}{lcclcc}
\hline & $\mathrm{f}$ & $\%$ & $\mathrm{f}$ & $\%$ \\
\hline Gender & & & Faculty graduated & & \\
Men & 50 & 70.4 & Faculty of education & 43 & 60.6 \\
Women & 21 & 29.6 & $\begin{array}{l}\text { Faculty of arts and sciences } \\
\text { Degree }\end{array}$ & 28 & 39.4 \\
School & & & & & \\
Public school & 52 & 73.2 & Bachelor's degree & 55 & 77.5 \\
Private school & 19 & 26.8 & Master's degree & 15 & 21.1 \\
School & & & Doctorate degree & 1 & 1.4 \\
Anatolia High school & 46 & 64.8 & Job experience (years) & & \\
Science High school & 10 & 14.1 & $1-10$ & 21 & 29.6 \\
Vocational high school & 14 & 19.7 & $\begin{array}{l}11-20 \\
\text { Over 20 }\end{array}$ & 39 & 54.9 \\
& & & & 10 & 14.1
\end{tabular}

Depending on which one do you follow the physics topics you teach during a year?

\begin{tabular}{|c|c|c|c|c|c|}
\hline Course book & 7 & 9.9 & Never & 4 & 5.6 \\
\hline Physics curriculum & 11 & 15.5 & Very little & 6 & 8.5 \\
\hline $\begin{array}{l}\text { Physics curriculum }+ \text { source } \\
\text { books }\end{array}$ & 5 & 7.0 & Little & 3 & 4.2 \\
\hline Annual plan & 21 & 29.6 & Medium & 20 & 28.2 \\
\hline Annual plan + Course book & 7 & 9.9 & Much & 25 & 35.2 \\
\hline $\begin{array}{l}\text { Annual plan + Physics } \\
\text { curriculum }\end{array}$ & 18 & 25.4 & Very much & 12 & 16.9 \\
\hline \multicolumn{3}{|c|}{$\begin{array}{l}\text { To what extend did you examine the physics } \\
\text { curriculum? }\end{array}$} & \multicolumn{3}{|c|}{$\begin{array}{l}\text { To which grades did you taught in the last three } \\
\text { years? }\end{array}$} \\
\hline Never & 1 & 1.4 & 9 grade & 2 & 2.8 \\
\hline Very little & 2 & 2.8 & 9 and 10 grade & 7 & 9.9 \\
\hline Little & 3 & 4.2 & 9 and 11 grade & 1 & 1.4 \\
\hline Medium & 26 & 36.6 & 11 and 12 grade & 1 & 1.4 \\
\hline Much & 19 & 26.8 & 12 grade & 1 & 1.4 \\
\hline \multirow[t]{3}{*}{ Very much } & 20 & 28.2 & 9,10 and 11 grade & 11 & 15.5 \\
\hline & & & 9,10 and 12 grade & 2 & 2.8 \\
\hline & & & $9,10,11$ and 12 grade & 44 & 62.0 \\
\hline
\end{tabular}




\section{Instrument}

In this research, physics teachers' knowledge about physics curriculum is investigated under three headings. Only grade 9 curriculum is taken into account in determining teachers' knowledge.

1. Their knowledge about the limitations that the curriculum imposed and to what extent they comply with these limitations,

2. Their knowledge about new concepts added to the curriculum and the extent to which they teach these concept in their courses

3. To what extent they comprehend the objectives in the curriculum.

To examine the above three main topics, certain number of objectives has been added to the survey to maintain a balance between the units of the grade 9 curriculum. The distribution of the objectives to the identified main topics are given in Table 3.

Table 3. The distribution of the objectives to the main topics of the study

\begin{tabular}{lcccc}
\hline Unit & Limitations & New concepts & Comprehensibility & Total \\
\hline Introduction to physics & 2 & 1 & 1 & 4 \\
Matter and its properties & 2 & 2 & 2 & 6 \\
Force and motion & 3 & 3 & 1 & 7 \\
Energy & 2 & 1 & 2 & 5 \\
Heat and temperature & 1 & 3 & 2 & 6 \\
Total & 10 & 10 & 8 & 28 \\
\hline
\end{tabular}

A survey questionnaire, which was prepared by the researchers, was used to collect data. The survey had four sections (see appendix), one for demographic features (12 items), one for limitations of the curriculum (11 items), one for new concepts added to the curriculum (11 items), and one for teachers' comprehension of the objectives (8 items).

The items in the survey was inspected by two expert teachers and three academic staff in order to determine the contextual validity of the questions. Except minor recommendations, experts' advices mostly lead to the addition of two more items which revealed why teachers comply with or not and why teach or not the objectives. Further description of the structure of the survey may cause confusion and take more space, that's why its summary is given in the appendix.

\section{Data collection and data analysis}

The survey stayed on the web for about two months. It was shared in the Facebook groups two times to attract the interest of more teachers. Beside the Facebook groups some of the data were collected from teachers through emails. They were friends of the researchers and the link of the survey was send to them by electronic mail.

In analyzing the data, firstly, data cleaning and missing data analysis was performed. Of the 84 data entry 11 were double entry and two were incomplete. Since the two incomplete cases did not constitute a considerable percentage, listwise deletion method was used. For statistical analysis, initially, the frequencies related to teachers responses on the three main topics (limitations, new concepts and the comprehensibility of the objectives) were tabulated. Then, because of the nature of the collected data contingency tables were constructed to conduct chi square analysis. Chi square analysis was conducted to see whether scores determined for each main topics changed according to school type, teaching experience, education level, graduated 
faculty and gender.

\section{Findings}

\section{Extent to which teachers comply with the limitations imposed by the curriculum}

To determine to what extend teachers obey the limitations imposed on the topics and teachers' knowledge about the limitations, of the 18 restrictions in the grade 9 physics curriculum 10 was included in the survey. Table 4 indicates the frequency regarding the degree to which teachers conform the restrictions.

Table 4. Frequencies of teachers' level of obeying the limitations in the curriculum

\begin{tabular}{lccc}
\hline Limitations (Objectives) & $\begin{array}{l}\text { Comply } \\
\text { with }\end{array}$ & $\begin{array}{l}\text { Do not } \\
\text { comply } \\
\text { with }\end{array}$ & $\begin{array}{l}\text { Does } \\
\text { not } \\
\text { exist }\end{array}$ \\
\hline Do not enter into calculations related to equal-arm balance & 37 & 28 & 6 \\
Do not enter into calculations related to density of mixtures & 29 & 37 & 4 \\
Do not enter into mathematical calculations other than applications with single & 24 & 41 & 6 \\
mass (Newton's second law) & 26 & 37 & 9 \\
Do not enter into mathematical calculations related to energy conversion & 47 & 20 & 5 \\
Do not draw position-time graph for accelerative motion & 15 & 39 & 18 \\
Do not enter into mathematical calculations related to Newton's laws of motion & 22 & 37 & 13 \\
Do not enter into calculations related to conversion of kinetic and potential & 47 & 20 & 6 \\
energy & 36 & 21 & 14 \\
Do not enter into calculations (expansion doe to heat change). & 55 & 15 & 2 \\
Do not enter into unit conversions and vector calculations & 33.8 & 29.5 & 8.3 \\
General characteristics of the gases are limited by the examples in daily life. & & & \\
Average & 53 \\
\hline
\end{tabular}

Table 4 demonstrate that a considerable amount of teachers, (12\%) are not aware of the presence of the limitation in the curriculum. For example 18 teachers $(25 \%)$ are not aware of the limitation "Do not enter into mathematical calculations related to Newton's laws of motion". Moreover, even though most teachers are aware of the limitations, many do not comply with these restrictions. In average, whilst $47 \%$ of teachers comply with the limitations put on the topics, a considerable amount of teachers $(41 \%)$ do not comply with the restriction. On the limitation basis, of the 72 teachers 41 of them (57\%) do not comply with the restriction specified as "Do not enter into mathematical calculations other than applications with single mass (Newton's second law)". Further, in average $12 \%$ of teachers do not know that these objectives exits in the curriculum.

In the survey the teachers were asked to specify the reason why they do not comply with the restrictions of the curriculum. Their general responses can be categorized as follows:

- Teaching physics without mathematics is difficult.

- Students understand and I teach.

- The restrictions disrupt the integrity of the topics

- National university entrance exams contain questions that do not obey these limitations.

- Source books and course book violate these restrictions and students try to solve questions from these books.

- Pilot tests for university entrance exams disregard the limitations 
- I want my students to learn physics thoroughly

- The restrictions are meaningless. Why not to teach for example the density of the mixtures.

- Other teachers contravene the limitations, so I don't want my students to be lag behind.

- Students want.

- The topic is well reiterated with mathematics.

\section{Teachers' teaching of new concepts added to the curriculum}

Many new concepts were added to the 2013 physics curriculum. For example, Amonton's experiment, Galileo's inclined plane experiment, perpetual motion machines and Galileo's ideas on the strength of bones of different thicknesses were some of them. Teachers' were requested to specify if they teach these concepts in their courses or not. Table 5 demonstrates teachers' responses on the new concepts added to the curriculum.

Table 5. Frequencies of teachers' teaching of the new concepts in the curriculum

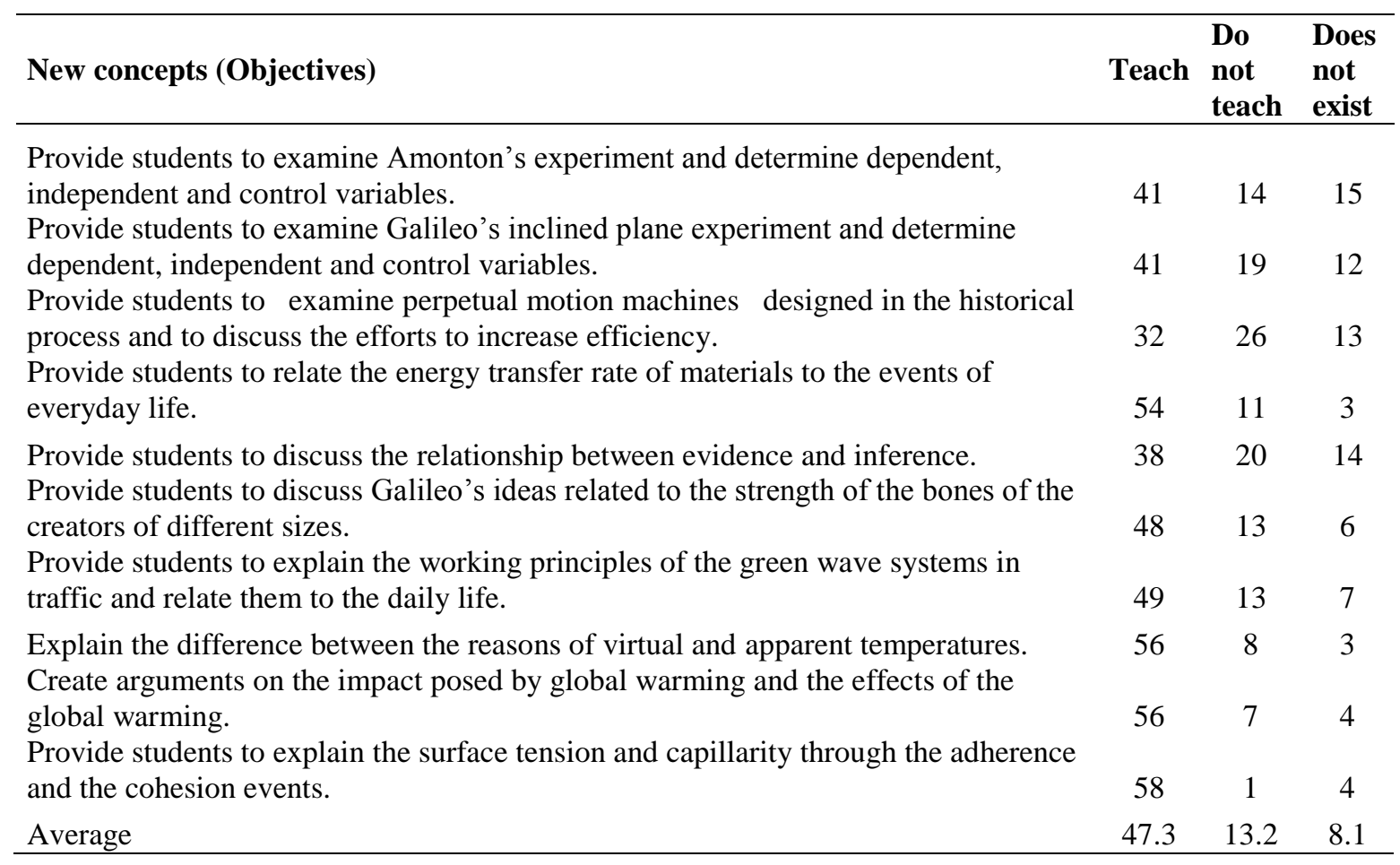

Table 5 indicates that more than half of the teachers $(66 \%)$ teach the new concepts while $18 \%$ of them do not teach the new concepts. Moreover, in average 8.1 teachers knows that these new concepts are not included in the curriculum. Among the ten objectives pertaining new concepts the perpetual motion machines are the most disregarded by teachers (36\%). Besides $21 \%$ of them are blind to the presence of the Amonton's experiment in the curriculum.

In the survey the teachers was asked to specify the reason why they do not teach the new concepts incorporated into the curriculum. Their general responses can be categorized as follows:

- They do not exist in the course book 
- They are the concepts that require discussion and experimentation, they took too much time.

- I don't have enough time.

- They do not draw students' interest.

- Questions related to these concepts are not asked in the source books.

- I don't have sufficient knowledge to teach these concepts.

- Concepts are not well explained in the course books

- Students do not understand and I rule out

\section{Teachers' comprehension of the objectives in the curriculum}

Some of the objectives in the physics curriculum are really vague. Teachers do not know what to do with these objectives. While some of the complications stem from wording of the sentences, some of them are due to unclear usage of the concepts in the objectives. For example, the phrase "science does not follow a particular method" in the following objective makes confusion: "In order to provide students to understand that the science does not follow a particular method, present examples from the history of science". Similarly the term "temperature change of the thermal equilibrium" makes confusion in the following objective: "Provide students to observe the relationship between the temperature change of the thermal equilibrium and heat, by using simulations and demonstrations". Table 6 represent eight ambiguous objectives in the curriculum along with responses collected from teachers. Since the objectives stated in Turkish language are vague, their translations to English become difficult.

Table 6. Frequencies of teachers' level of comprehension of the concepts in the curriculum

\begin{tabular}{|c|c|c|c|c|}
\hline Comprehension & Comprehend & $\begin{array}{c}\text { Partially } \\
\text { Comprehend }\end{array}$ & $\begin{array}{l}\text { Do not } \\
\text { Comprehend }\end{array}$ & $\begin{array}{l}\text { Do not } \\
\text { exist }\end{array}$ \\
\hline $\begin{array}{l}\text { Provided students to associate the daily life with } \\
\text { the study areas which benefit from the density } \\
\text { (such as jewelry, porcelain production). }\end{array}$ & 51 & 13 & 2 & 1 \\
\hline $\begin{array}{l}\text { Provide students to observe the relationship } \\
\text { between the temperature change of the thermal } \\
\text { equilibrium and heat by using simulations and } \\
\text { demonstrations. }\end{array}$ & 38 & 11 & 4 & 9 \\
\hline $\begin{array}{l}\text { Students are provided to discuss the different } \\
\text { features of the force through its observable effects. }\end{array}$ & 50 & 7 & 7 & 6 \\
\hline $\begin{array}{l}\text { Present examples from the history of science in } \\
\text { order to provide students to understand that the } \\
\text { science does not follow a particular method. }\end{array}$ & 43 & 8 & 7 & 10 \\
\hline $\begin{array}{l}\text { Provide students to analyze the mathematical } \\
\text { models of work and power concepts. }\end{array}$ & 44 & 6 & 4 & 8 \\
\hline $\begin{array}{l}\text { Provide students to explain the surface tension and } \\
\text { capillarity through the adherence and cohesion } \\
\text { events. }\end{array}$ & 49 & 6 & 2 & 3 \\
\hline $\begin{array}{l}\text { Provide students to give examples of the effects of } \\
\text { changes in temperature of substances having } \\
\text { different specific heats in the daily life. }\end{array}$ & 47 & 8 & 3 & 3 \\
\hline $\begin{array}{l}\text { Provide students to explain that the energy can be } \\
\text { transferred from a substance or system to another } \\
\text { on the daily life examples. }\end{array}$ & 45 & 4 & 3 & 4 \\
\hline Average & 45.9 & 7.9 & 4.0 & 5.5 \\
\hline
\end{tabular}

As seen in Table 6 while in average eight teachers (11\%) partially comprehend the objectives, 
four of them (6\%) do not understand what is meant by the objective. Further, in average $8 \%$ of teachers do not aware of the existence of these objectives in the curriculum. On the objective basis, for the objective "Present examples from the history of science in order to provide students to understand that the science does not follow a particular method" a total of 17 teachers either partially understand or do not understand what to do for this objective. Moreover, among these objectives the one with least comprehension was "Provide students to observe the relationship between the temperature change of the thermal equilibrium and heat by using simulations and demonstrations" (38 teachers, 53.5\%).

\section{The variance of the three stages of teachers' use of curriculum across gender, graduated faculty, school type and school experience}

As a consequence of the last research question the relations between the three stages of teachers' use of curriculum and personal characteristics are summarized in Table 7. The chi-square test for homogeneity was used to discover if there was a difference between personal characteristics of teachers and dependent variables; limitations on the topics, teaching the new concepts and teachers' comprehension of the objectives. Several findings can be inferred from Table 7 .

Table 7. Chi square statistics

\begin{tabular}{|c|c|c|c|c|c|}
\hline Independent variable & Dependent Variable & $\chi^{2}$ & df & $\mathrm{p}$ & $\eta^{2}$ \\
\hline \multirow{4}{*}{ Type of School (Public, Private) } & Limitations on the topic & .230 & 1 & .63 & .019 \\
\hline & Teach new concept & 4.68 & 1 & .03 & .088 \\
\hline & Comprehend the objective & 4.43 & 2 & .11 & .098 \\
\hline & Limitations on the topic & 18.0 & 2 & .00 & .167 \\
\hline \multirow{2}{*}{$\begin{array}{l}\text { Type of School (Anatolia, } \\
\text { Vocational, Science) }\end{array}$} & Teach new concept & 11.05 & 2 & .004 & .135 \\
\hline & Comprehend the objective & 4.01 & 4 & .41 & .066 \\
\hline \multirow{3}{*}{ Degree (Bachelor, Graduate) } & Limitations on the topic & 1.50 & 1 & .21 & .049 \\
\hline & Teach new concept & 6.02 & 1 & .014 & .100 \\
\hline & Comprehend the objective & 3.02 & 2 & .22 & .081 \\
\hline \multirow{3}{*}{$\begin{array}{l}\text { Graduation (Faculty of education, } \\
\text { Faculty of art and science }\end{array}$} & Limitations on the topic & .47 & 1 & .50 & .027 \\
\hline & Teach new concept & 1.36 & 1 & .24 & .047 \\
\hline & Comprehend the objective & 1.65 & 2 & .44 & .060 \\
\hline \multirow{3}{*}{$\begin{array}{l}\text { Years of experience in } \\
\text { teaching physics }\end{array}$} & Limitations on the topic & 12.31 & 2 & .002 & .139 \\
\hline & Teach new concept & 4.44 & 2 & .11 & .086 \\
\hline & Comprehend the objective & 22.90 & 4 & .000 & .159 \\
\hline \multirow{3}{*}{ Gender } & Limitations on the topic & .49 & 1 & .49 & .027 \\
\hline & Teach new concept & 2.85 & 1 & .09 & .069 \\
\hline & Comprehend the objective & 18.23 & 2 & .000 & .199 \\
\hline
\end{tabular}

Initially, for the type of school (public and private) there was a significant relation only between school type and teaching the new concepts $\left(\chi^{2}(1)=4.68, \mathrm{p}<.05\right)$. In other words, private school teachers teach the new concepts added to curriculum in their courses $(84.2 \%)$ more (See Table 7) than the public school teachers (75.9\%). Moreover, even though the difference between the public (47.6\%) and private (49.7) school teachers is not significant, the amount of limitations that they do not comply with is high enough. Contrary, the degree of 
comprehension of the objectives for school type is also statistically not significant, however, the rate of the objectives that teachers do not comprehend is low for both school types $(7.8 \%$ for public and $3.4 \%$ for private).

Secondly, for the other classification of schools (Anatolia, Vocational, Science) statistically significant relation was observed both between school type and the limitations put on the topics $(\chi 2(2)=18.0, \mathrm{p}<.05)$, and school type and the teaching the new concepts $\left(\chi^{2}(2)=\right.$ $11.05, \mathrm{p}<.05)$. In other saying, vocational high school teachers comply with $(61.7 \%)$ the restrictions put on the topics in the curriculum more than Anatolia (53.2\%) and science high school teachers $(34.9 \%)$. Similarly, science high school teachers teach new concepts added to the curriculum (87\%) more than Anatolia (78.5\%) and vocational school teachers $(69.2 \%)$. Moreover, the percentages of the teachers that do not comprehend the objectives in Science, Anatolia and vocational school are 4.8\%, 7.8 and 5.3 respectively. The difference between these percentages are not significant.

Thirdly, for the degrees teachers have from university, the only significant difference appear in the teaching of new concepts $(\chi 2(1)=6.02, \mathrm{p}<.05)$. Put it differently, graduated teachers (those have master or $\mathrm{PhD}$ degree) teach new concepts more $(85.6 \%)$ than the teachers have bachelor degree $(75.8 \%)$. Moreover, in spite of no significant difference, a considerably more amount of teachers both having bachelor and graduate degrees to not conform the limitations put on the topics; $49.5 \%$ and $43.7 \%$ respectively. Contrary, their lack of comprehension of the objectives is not that much; bachelor degree's level of partially comprehension and not comprehension are $12.7 \%$ and $5.8 \%$ respectively and that of graduate degree are $15.8 \%$ and $9.6 \%$ respectively.

Fourthly, in terms of faculty of graduation no significant differences were identified between teacher groups (See Table 7). However, a highly big proportion of teachers do not comply with the constraints imposed on the physics topics in the curriculum. $49.2 \%$ of teachers graduated from faculty of education and $46.5 \%$ graduated from faculty of art and science do not comply with the restrictions placed on the topics. Contrary, percentages of not teaching the new concepts are not as much as percentages of limitations $(23.5 \%$ and $19.5 \%$ respectively). Besides, percentages for the partially comprehension and not comprehension is relatively much lower, yet not at desired level (See Table 7).

Fifthly, in terms of years of experience in teaching physics, significant differences were observed both between experience and the limitations imposed on the topics $(\chi 2(2)=12.31$, $\mathrm{p}<.05)$, and the experience and the level of comprehension of the objectives $(\chi 2(4)=22.90$, $\mathrm{p}<.05)$. In other words, the rate of complying with the restrictions in the curriculum for 1-10 years, 11-20 years and over 20 years significantly differ from each other $(51.3 \%, 48.0 \%$ and $69.0 \%$ respectively). Likewise, the level of comprehension of the objectives, $81.9 \%, 76.3 \%$ and $89.5 \%$ correspondingly, also diverge significantly. These means that teachers having experiences over 20 years both conform the restrictions and comprehend objectives more than the teachers having 1-10 years and 11-20 years of experiences.

Sixthly, for gender, whilst teachers' degree of obeying the limitations imposed by the curriculum does not vary across gender, significant differences were observed among teacher groups (female and male) both in teaching the new concepts $(\chi 2(1)=2.85, \mathrm{p}<.05)$ and comprehension of the objectives $(\chi 2(2)=18.23, \mathrm{p}<.05)$. In other saying, female teachers teach the new concepts added to the curriculum more (82.6\%) than male teachers $(76.3 \%)$ and their comprehension of the objectives is also more than that of male teachers $(92.2 \%$ and 
$75.0 \%$ respectively). Further, although the difference is not significant, a substantial amount of female $(46.0 \%)$ and male teachers $(49.0 \%)$ do not comply with the restrictions imposed on the topics by the curriculum. Furthermore, the rate of teachers that do not teach new concepts are $17.4 \%$ for female and $23.7 \%$ for male teachers.

Table 8. Percentages across groups regarding stages of teachers' using the curriculum

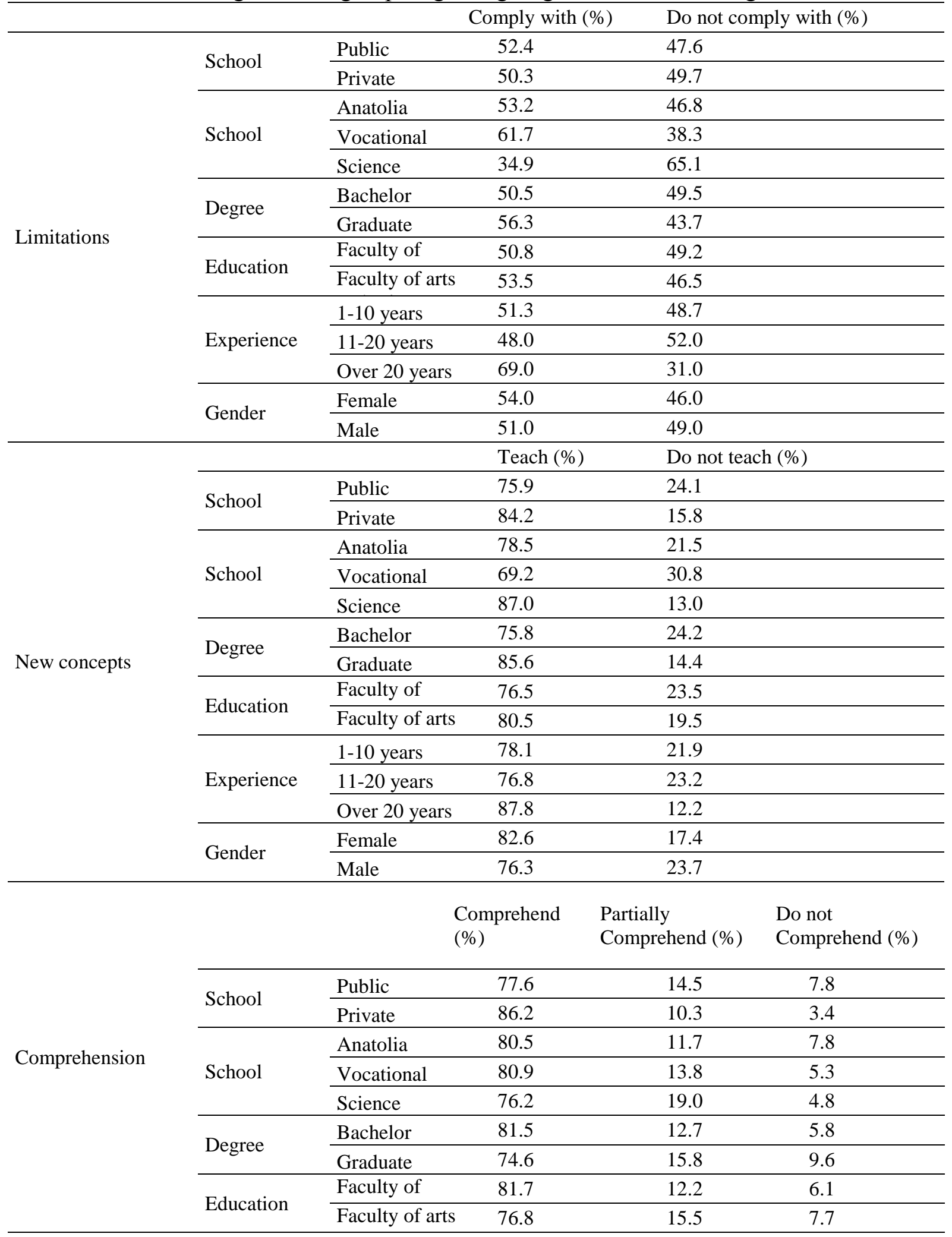




\begin{tabular}{llllll}
\hline \multirow{4}{*}{ Experience } & $1-10$ years & 81.9 & 18.1 & .0 \\
\cline { 2 - 6 } & & $11-20$ years & 76.3 & 13.6 & 10.1 \\
\cline { 2 - 6 } & Over 20 years & 89.5 & 1.8 & 8.8 \\
\cline { 2 - 6 } & \multirow{2}{*}{ Gender } & Female & 92.2 & 7.0 & .8 \\
\cline { 2 - 5 } & Male & 75.0 & 16.0 & 9.0 \\
\hline
\end{tabular}

\section{Discussion and Conclusions}

In this study, we investigated the state of physics teachers to recognize and apply the physics curriculum (its limitations, new subjects and concepts) that was revised in 2013 and comparatively analyzed it in terms of the selected parameters.

As is known; the new physics curriculum aims to add meaning to physics subjects, which are detracted from their context and conceptual structure and reduced to only mathematical operations, once again (Yiğit et al., 2012). In this context, in contradistinction to the judgment "physics cannot exist without maths" that has been sustained for years; the physics lesson curriculum has made important limitations in terms of mathematical operations. This condition is a natural result of the philosophy of the new curriculum, which grounds on conceptual learning. It is very important for teachers, who are the implementers of curricula, to comply with and know these limitations in order to enable the curriculum to achieve its goal (Balta \& Eryilmaz, 2010). Thus, this study examined the state of participants to comply with and know the limitations of the curriculum.

According to the acquired findings, a considerable part of participants were not even aware of the limitations of the curriculum and almost half of them did not comply with these limitations in their classes (respectively $12 \%$ and $41 \%$ ). Less than half of participant teachers $(47 \%)$ complied with limitations that were substantially related with the failure of teaching mathematical operations, which is thought to be a remarkable issue. This condition could be associated with the habits of physics teachers. The data regarding the state of participant teachers to recognize the new subjects/concepts or objectives added to the curriculum and involve them in their lessons show that a considerable part of teachers do not consider the additions in the curriculum. It is observed that a considerable group of participants (18\%) do not involve new concepts and subjects in the curriculum, which could generally be associated with indifference of students and the problem of time and most importantly the failure of relevant teachers to internalize the changes in the curriculum. It is also observed that some studies focusing on the changes in curricula from different aspects (for instance, Özmantar et al. 2009) note that teachers fail in internalizing the change in curricula, which is defined as reform.

The analysis of the physics lesson curriculum that was performed within the scope of this study shows that new objectives were added to the curriculum along with general explanations regarding these objectives (for instance, science does not follow a particular method). Such objectives in the curriculum were determined and the state of teachers to comprehend these objectives and explain their meaning was analyzed. In this context, it was determined that an important part of participants could explain the meaning of these objectives, whereas a considerable part of them could not explain or realize them. The failure of even a small part of teachers who were supposed to have a good comprehension of the curriculum to explain the meaning of objectives and especially realize their presence signifies the existence of greater problems. 
Analyzing the findings that were acquired in terms of different parameters (gender, graduated faculty, school type and school experience); some important results were obtained within the scope of the study. It was determined that a great majority of teachers working at private and public schools taught the new concepts/subjects added to the curriculum; however, this rate was a little higher in teachers working at private schools.

Additionally, vocational high school teachers comply with the restrictions put on the topics in the curriculum more than Anatolia and science high school teachers. Similarly, science high school teachers teach new concepts added to the curriculum more than Anatolia and vocational school teachers.

Graduated teachers (those who have a master or $\mathrm{PhD}$ degree) teach new concepts more $(85.6 \%)$ than the teachers who have a bachelor degree $(75.8 \%)$. This condition could be associated with the fact that teachers who had completed their postgraduate education are more familiar with new approaches and have a positive attitude toward developing themselves professionally. Such applications that are not so common in our country have been extended in some countries (like Britain, France, Denmark) that are accepted to be qualified in the field of education for the purpose of having "professional development" (Sağlam Arslan, 2009). This result that is on behalf of teachers with $\mathrm{PhD}$ reveals the positive effects of postgraduate education upon the profession of teaching, which has started to become stationary in the course of time due to various reasons.

Being different from studies indicating that teachers with a greater professional experience have a greater difficulty in adapting to renewed curricula than others (Gökçek, 2008); in this study, teachers having experiences over 20 years both conform the restrictions and comprehend objectives more than the teachers having 1-10 years and 11-20 years of experiences. The rate of complying with the restrictions in the curriculum for 1-10 years, 1120 years and over 20 years significantly differ from each other $(51.3 \%, 48.0 \%$ and $69.0 \%$ respectively). Likewise, the level of comprehension of the objectives, $81.9 \%, 76.3 \%$ and $89.5 \%$ correspondingly, also diverge significantly.

Female teachers teach the new concepts added to the curriculum more (than male teachers and their comprehension of the objectives is also more than that of male teachers). This result is different from the study of Arslan, Ercan and Tekbiy1k (2012) which indicates that the views of teachers regarding the curriculum show a significant difference on behalf of male teachers. Considering this result, it could be asserted that the change according to gender depends on sample and there is no way of making a generalization depending on gender.

\section{Suggestions}

Considering the results obtained from this study, it could be suggested to apply new approaches that would support the constant development of teachers in service. In this context, it could be suggested to design mentorship applications for teachers, who enable long-term applied studies, as an alternative to In-Service Educational Activities that are conducted by MEB and have important malfunctions in the process of execution according to various studies (Balta, Arslan \& Duru, 2015; Çimer, Çakır \& Çimer, 2010; Miser, Yayla \& Sayın, 2006; Ayas et al. 2007).

On the other hand, it is thought that changing the general structure of Group Teacher Committee meetings, which are organized at certain times within the school year, are considered an activity that encourages subject matter teachers at same schools to make 
common decisions and conduct applications for reaching the success (Kaya, Çepni \& Küçük, 2004; Şahin et al., 2011), but have important problems while being applied (Karal Eyüboğlu \& Sağlam Arslan, 2015), would contribute to the compliance of teachers with the constantly renewed curricula.

\section{References}

Ayas, A., Özmen, H., Demircioğlu, G. \& Sağlam, M. (1999). Türkiye'de ve Dünyada Yapılan Program Geliştirme Çalışmaları: Kimya Açısından Bir Derleme [Curriculum development studies in Turkey and in the World: A compilation in terms of chemistry]. Dokuz Eylül University Buca Journal of Education special issue, 11, 211219.

Ayvac1, H. Ş. (2010). Views of physics teachers about context based approach. Dicle University Ziya Gökalp Journal of Education, 15, 42-51.

Arslan, A., Ercan, O. \& Tekbıyı, A. (2012). Fizik dersi yeni ögretim programına ilişkin ögretmen görüşlerinin çeşitli değişkenler açısından değerlendirilmesi [Assessment of teachers' views regarding new physics curriculum in terms of various variables]. Paper presented at the X National Science and Mathematics Educational Congress, Niğde, Turkey

Balta, N. (2015). A Systematic Planning for Science Laboratory Instruction: Research-Based Evidence. Eurasia Journal of Mathematics, Science \& Technology Education, 11(5), 957-969.

Balta, N., Arslan, M., \& Duru, H. (2015). The Effect of In-Service Training Courses on Teacher Achievement: A Meta-analysis Study. Journal of Education and Training Studies, 3(5), 254-263.

Balta, N., \& Eryilmaz, A. (2010). Turkish new high school physics curriculum: teachers' views and needs. Eurasian Journal of Physics and Chemistry Education, 1(1), 72-88.

Bulut, M. (2007). Curriculum Reform in Turkey: A Case of Primary School Mathematics Curriculum. Eurasia Journal of Mathematics, Science \& Technology Education, 3(3), 203-212.

Creswell, J. W. (2012). Educational research: Planning, conducting and evaluating quantitative and qualitative research (4th Edition). Boston: Pearson Education.

Çimer, S., Çakır, İ., \& Çimer, A. (2010). Teachers' Views on the Effectiveness of In-Service Courses on the New Curriculum in Turkey. European Journal of Teacher Education, 33(1), 31-41.

Daramola, S. O., \& Omosewo, E. O. (2012). An appraisal of the new Nigerian senior secondary school physics curriculum. Journal of Education and Practice, 3(8), 191194.

Erdoğan, M. \& Köseoğlu, F. (2012). Analysis of High School Physics, Chemistry and Biology Curriculums in terms of Scientific Literacy Themes. Educational Sciences: Theory \& Practice, 12(4): 2889-2904.

Gökçek, T. (2008). 6. sınıf matematik ögretmenlerinin yeni ilköğretim programına uyum sürecinin incelenmesi [Examination of sixth grade mathematics teachers? adaption process to new elementary curriculum] (Unpublished doctoral dissertation). Karadeniz Technical University, Trabzon, Turkey

Kaya, A., Çepni, S. \& Küçük, M. (2004). Fizik Öğretmenleri için Üniversite Destekli bir Hizmet içi Eğitim Model Önerisi [A suggestion of university supported in-service training course for physics teachers], The Turkish Online Journal of Educational Technology, 3 (1) 112-119. 
Kapucu, S. (2010). Yeni fizik müfredatının uygulanmasında öğretmenlerin karşılaştıkları sorunlar ve çözüm önerileri [Problems faced by teachers in implementing the new physics curriculum and solutions]. I. Online Workshop. http://fizikli.com/box/?page_id=58

Karal Eyüboğlu, I. S. \& Saglam Arslan, A. (2015, September). Fizik Zümre Öğretmenlerinin Okul Zümre Toplantılarına İlişkin Düşünce ve Uygulamalarının Nedenleri [Physics teachers' views regarding physics meeting in schools and causes of the practice]. Paper presented at the II National Physics Educational Congress, Ankara, Turkey

Miser, R., Yayla, D. \& Sayın, M. (2006). Milli Eğitim Bakanlığı Hizmetiçi Eğitim Faaliyetlerinin Değerlendirilmesi [Assessment of Ministry of Education in-service education activities]. Ministry of National Education, EARGED, Ankara.

Özmantar, M.F., Bingölbali, E., Dmie, S., Sağlam, Y. \& Keser, Z. (2009). Değişen Öğretim Programları ve Sınıf İçi Normlar [Curriculum reform and the classroom norms]. International Journal of Human Sciences, 6(2), 1-23.

Sarıkaya, M., Güven, E., Göksu, V. \& İnce Aka, E. (2010). The Impact of Constructivist Approach on Students' Academic Achievement and Retention of Knowledge. Elementary Education Online, 9(1), 413-423.

Şahin, E. Y., Maden S. \& Gedik, M. (2011). Zümre Öğretmenler Kurulu Toplantılarının Etkililiğinin Türkçe Öğretmenlerinin Görüşlerine Dayalı Olarak Değerlendirilmesi (Erzurum İli Örneği) [An evaluation of the effectiveness of committees of teachers based on the views of Turkish language teachers (a sample of Erzurum)]. Erzincan University Journal of education, 13(1), 155-172.

Özsevgeç, T. (2007). İlköğretim 5. Sinıf Kuvvet ve Hareket Ünitesine Yönelik 5E Modeline Göre Geliştirilen Rehber Materyallerin Etkililiklerinin Belirlenmesi [Determining effectiveness of guided materials about force and motion unit based on the 5E model for elementary students] (Unpublished doctoral dissertation). Karadeniz Technical University, Trabzon, Turkey.

Paliç, G. (2014). Modern Fizik Ünitesine Yönelik 7E Öğretim Modeline Uygun Tasarlanan Materyalin Etkisinin Incelenmesi [Investigation effectiveness of designed material for modern physics unit of high school education in accordance with 7E teaching model] (Unpublished doctoral dissertation). Karadeniz Technical University, Trabzon, Turkey.

Paliç, G. \& Akdeniz, A. R. (2012). Beyin Temelli Öğrenmeye Dayalı Web Destekli Bir Öğretim Materyalinin Tasarlanması ve Değerlendirilmesi [Designing and Evaluating a Web Supported Instructional Material based on Brain Based Learning]. Necatibey Faculty of Education Electronic Journal of Science and Mathematics Education, 6(1), 67-93.

Sağlam Arslan, A., Devecioğlu, Y. \& Arslan, S. (2013). Conformite des Pratiques d'evaluation des Enseiganants de «Science et Technolohie » avec les Programmes Officiels. Hacettepe University Journal of Education, 28(1), 320-333.

Sağlam Arslan, A., Devecioğlu Kaymakçı, Y. \& Arslan, S. (2009). Alternatif Ölçme Değerlendirme Etkinliklerinde Karşılaşılan Problemler: Fen ve Teknoloji Öğretmenleri Örneği [Problems concerning alternative evaluation methods: the case of science and technology teachers], Ondokuz Mayls University Journal of education, 28, $1-12$.

TEDMEM. (2015). Türkiye eğitim atlast 2014-2015 [Turkey training atlas 2014-2015], Turkish Education Association, Karınca Press, Ankara, Turkey.

Tekbıyık, A. \& Akdeniz A. R. (2008). İlköğretim Fen ve Teknoloji Dersi Öğretim Programını Kabullenmeye ve Uygulamaya Yönelik Öğretmen Görüşleri [Teachers' Views about Adoption and Application of Primary Science and Technology Curriculum], Necatibey 
Faculty of Education Electronic Journal of Science and Mathematics Education, 2(2), 23-37.

Tekbıyık, A. (2010). Bağlam Temelli Yaklaşımla Ortaöğretim 9. Sınıf Enerji Ünitesine Yönelik 5E Modeline Uygun Ders Materyallerinin Geliştirilmesi [Development of course materials integrating context based approach into 5E model in terms of energy unit for 9th grade secondary students] (Unpublished doctoral dissertation). Karadeniz Technical University, Trabzon, Turkey.

Toptaş, V. (2006). İlköğretim Matematik dersi (1-5). Öğretim Programının Uygulanmasında Sınıf Öğretmenlerinin Karşılaştıkları Sorunlarla İlgili Görüşleri [Classroom Teachers' Opinions Concerning the Problems in Implementation of Curriculum, Primary school Mathematics (1-5)]. National primary school teaching congress, proceedings, 1, 277285. Ankara: Kök Press. Turkey

Turkish Physics Curriculum. (2013). Ortaöğretim fizik dersi 9, 10, 11 ve 12 sinıflar öğretim programı [High school 9, 10, 11 and 12 grade physics curriculum]. Retrieved March 2016 from http://ttkb.meb.gov.tr/www/guncellenen-ogretim-programlari/icerik/151

Yiğit, N., Alev, N., Tural, G. \& Bülbül, M. Ş. (2012). Fen bilgisi I. sınıf öğretmen adaylarının elektrik konusundaki problemleri anlama ve çözme durumları üzerine bir araştırma [An Investigation on Science Students' Understanding and Solving Of Electric Problems]. Cumhuriyet International Journal of Education, 1(2), 18-36. 


\section{Appendix}

Precious teacher,

This study investigates to what extent physics teachers use the $9^{\text {th }}$ grade physics curriculum. This study is conducted completely on a volunteer basis. Since this study will shape on the data collected from you, your responses have a place. Please leave your name and answer all the items. All information collected in this survey will be kept strictly confidential.

Section 1:

A1. Gender:

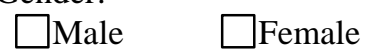

A2. Type of school you work
$\square$ Public
$\square$ Private

A11. Do you have difficulty examining the physics curriculum? Explain your answer.

\section{Section 2:}

SHOULD BE READ CAREFULLY: The items in this section are concerned with limitations on the objectives of the $9^{\text {th }}$ grade physics curriculum. If you know that the limitations exists in the curriculum please mark "Exist", if you do not know mark "Do not exist". Then, if you comply with the limitation mark "I comply with", if you do not comply with it mark " I do not comply with". Pay attention that if you mark "exist", must mark one more choice.

B1. Do not enter into calculations related to equal-arm balance

$\square$ Exist $\square$ I comply with $\square$ I do not comply with $\square$ Do not exist

$\cdots$

B11. If you do not comply with the one or more of these limitations please write the cause.

Section 3:

SHOULD BE READ CAREFULLY: The items in this section are concerned with new concepts added to the $9^{\text {th }}$ grade physics curriculum. If you know that the objective exists in the curriculum please mark "Exist", if you do not know mark "Do not exist". Then, if you mark "exist" if you teach it in your course mark "I teach", if you do not teach it mark " I do not teach". Pay attention that if you mark "exist" must mark one more choice.

C1. Provide students to examine Amonton's experiment and determine dependent, independent and control variables.

$\square$ Exist $\square$ I teach $\square$ I do not teach $\square$ Do not exist

B11. If you do not teach one or more of these objectives please write the cause.

Section 4:

SHOULD BE READ CAREFULLY: The items in this section are concerned with the comprehensibility of the objectives of the $9^{\text {th }}$ grade physics curriculum. If you know that the objective exists in the curriculum please mark "Exist", if you do not know mark "Do not exist". Then, if you understand what it means mark "I comprehend", if you partially understand mark "I partially comprehend", if you do not understand mark "I do not comprehend". Pay attention that if you mark "exist" must mark one more choice.

D1. Students are provided to associate the daily life with the study areas which benefit from the density (such as jewelry, porcelain production).

$\square$ Exist $\square$ I comprehend $\square$ I partially comprehend $\square$ I do not comprehend 